\title{
BANK COMPETITION-STABILITY RELATIONS IN PAKISTAN: A COMPARISON BETWEEN ISLAMIC AND CONVENTIONAL BANKS
}

\author{
M. Kabir Hassan* \\ University of New Orleans, USA \\ Muhammad Shahzad Ijaz \\ Capital University of Science and Technology, Pakistan \\ Mushtaq Hussain Khan \\ University of Azad Jammu \& Kashmir, Pakistan
}

\begin{abstract}
This study comparatively analyses the financial stability of Islamic and conventional banks in Pakistan. Using data of 29 conventional and 9 Islamic banks over 18 years, the study first estimates bank competition and stability using Lerner index and Z-Score, respectively. Generalized least squares regression is used and the coefficients are estimated by using random-effects estimator. Results of the mean comparison show that Islamic banks carry more market power (less competition) and are more stable compared to their conventional counterparts. Results of a panel regression show that competition positively affects the stability of the banking sector and this effect is higher for Islamic banks due to their market power. Results also show that bank stability in Pakistan was reduced during global crisis period; however, presence of Islamic banks contributes to the stability even during crisis. Finally, this study supports the competition-stability hypothesis for Islamic banking in Pakistan. Recommendations are given at the end.
\end{abstract}

Keywords: Stability, Bank Competition, Islamic Banking, Z-Score, Lerner Index.

Received: 13 July 2020

Accepted: 1 April 2021

https://doi.org/10.33736/ijbs.3733.2021

\section{INTRODUCTION}

The association between competition and bank stability remains an extensively debated issue, both among academics and policy-makers (Beck et al., 2013; Clark et al., 2018; Ijaz et al., 2020; Kasman \& Kasman, 2015, among others). Interestingly, recent years have seen renewal of interest in competition and bank stability and researchers have explored this association in dual banking system where Islamic and conventional banks operate alongside each other. In this regard, Abedifar et al. (2016) have theoretically discussed that how the presence of both Islamic and conventional banks shapes competitive environment in dual banking system. Particularly, the competition

\footnotetext{
* Corresponding author: Professor of Finance and Hibernia Professor of Economics and Finance and Bank One Professor in Business, Department of Economics and Finance, University of New Orleans, Orleans, USA; Cell: +1 (610) 529-1247; Email: mhassan@uno.edu
} 
pressure might be even stronger on conventional than Islamic banks, because Muslims with religious concerns would prefer Islamic to conventional finance, however, other Muslims are expected to be indifferent between the two systems (Abedifar et al., 2016). Recently, subsequent studies have empirically investigated the association between competition and stability in dual banking system, for instance, a study by Albaity et al. (2019) focus on MENA countries while Kabir and Worthington (2017) on number of Muslim countries. Likewise, Ibrahim et al. (2019) study this issue for the Malaysian banking industry.

Based on aforementioned work on competition-stability nexus in dual banking system, this study aims to investigate this association for unexplored area of Pakistani market. Literature is scarce on the association of competition-stability from the perspective of Islamic banks in the Pakistani context. Specifically, the extant literature focused mainly on the comparative performance of Islamic banks in relation to conventional counterparts. This study argues that existence of the dual banking system makes Pakistani market as an exceptional setting to study whether the competition between Islamic and conventional banking industry affects bank stability. In Pakistan, the inception of Islamic banking and substantial growth in the number of Islamic banks has shaped the competitive environment for conventional banking system. As of September 2020, the State Bank of Pakistan reported ${ }^{\mathbf{1}}$ that Islamic banking industry has 22 Islamic banking institutions with 5 fullfledged Islamic banks and 17 conventional banks having standalone Islamic banking branches. Moreover, in total 3,303 branches are operating all over the Pakistan. Banking sector in Pakistan has developed in three stages including conventional banking (1948-1980), profit and loss sharing (PLS) banking (1980s and 1990s) to the current mix of PLS and Shariah-compliant banking. The Islamic banking was incepted in Pakistan in February 1979 with the intention to make interest free economy (Rashid et al., 2017). However, in 2002 a swift progress has been observed in Islamic banking sector when it declared as a parallel mode of banking alongside conventional banking.

This study contributes to conventional and Islamic banking literature in the following ways. First, a recent study by the State Bank of Pakistan estimates the degree of competition in Pakistani banks; however, its connection with the stability of the sector remains unexplored (Hanif, 2017). In this regard, our study is the first to the best of authors' knowledge in the Pakistani context that considers the influence of bank competition on bank stability in dual banking system. Hence, this study contributes to the emerging literature on Islamic banking. As most of the Islamic countries are trying to develop an Islamic financial system, our results provide important insights whether competition between conventional and Islamic banks is linked with the stability to the financial system.

Second, a comparative analysis of competition and stability relationship is presented for Islamic and conventional banks operating alongside each other in dual banking system. Hence, this study we complement the works of Abedifar et al. (2013), Abedifar et al. (2017), Beck et al. (2013), Hasan and Dridi (2011), Khan et al. (2020) and Mollah and Zaman (2015). These studies provide comparative analyses of financial stability, risk management, performance, and efficiency between these two types of banks.

Third, competition is measured using a direct measure of market power instead of concentration measures (CR3 and CR5 that measures the share of total assets in 3 and 5 largest banks of the

\footnotetext{
${ }^{1}$ Islamic Banking Bulletin, September 2020. https://www.sbp.org.pk/ibd/Bulletin/2020/Sep.pdf
} 
country) under the industrial organization approach. These concentration ratios are considered a weaker measure of competition in banking. Fourth, the difference in bank stability and competition is separately compared across dual banking (Islamic as well as conventional banks) in Pakistan.

\section{LITERATURE REVIEW}

Theoretically, there are two key alternative hypotheses that suggest whether competition impedes or improves the bank stability: competition-fragility hypothesis and competition-stability hypothesis. On the one hand, competition fragility hypothesis (Keeley, 1990) assumes that competition erodes stability. This is because, in the banking sector, fierce competition has forced banks to take excessive risks in the search for returns, resulting in higher fragility. Moreover, in an environment of fierce competition, banks earn fewer informational rents from their relationship with borrowers, reducing their incentives to properly screen borrowers, again increasing the risk of fragility (Allen \& Gale, 2004; Boot \& Thakor, 1993). On the other hand, the competitionstability hypothesis posits that more competitive banking environment leads to higher stability rather than less stability. Moreover, intensified competition makes the financial system more flexible (Boyd \& De Nicoló, 2005), thereby highly competitive banking sectors lead to declines in lending rates and support for the profitability of enterprises, resulting in lower bank credit defaults. Besides, contrary to the competitive banking environment, in a monopolistic environment, banks are more likely to engage in moral hazard based on their own too-big to fail positions (Mishkin, 1999).

In conventional banking literature, numerous of studies have investigated the impact of competition on bank stability in general and findings are inconclusive. For instance, on the one hand studies report the positive impact of competition on bank stability (Clark et al., 2018; Goetz, 2018; Islam et al., 2020; Kasman and Kasman, 2015; Saif-Alyousfi et al., 2020). On the other hand, studies show a negative impact of competition on bank stability (Beck et al., 2013; Ijaz et al., 2020).

In case of the dual banking system, recent studies investigated the competition-stability nexus in dual banking exacerbated by the presence of both Islamic and conventional banks. For instance, Kabir and Worthington (2017) explored the association of competition and stability for Islamic and conventional counterparts using the data for sixteen developing economies over the period of 2000 through 2012. They found that competition in terms of market power have significantly greater impact on conventional banks. Likewise, Ibrahim et al. (2019) investigated the competitionstability relationship using the sample of conventional and Islamic banks from Malaysian market. Their results also support the competition-stability view for conventional banks.

Moreover, Albaity et al. (2019) examined the competition-stability relationship using the dataset of 276 banks from eighteen MENA countries for the period of 2006 to 2015. They noted a strong competition-fragility effect for Islamic banks compared to their conventional counterparts. Alternatively speaking, Islamic banks in less competitive environment face lower insolvency risk and become more stable. Azmi et al. (2019) studied the relationship between competition and bank stability for both Islamic and conventional banks for fourteen dual banking economies over the period of 2005 to 2016. However, they noted no significant difference in the relationship between competition and stability for both type of banks. 
In the similar stream of research, Alam et al. (2019) investigated the impact of competition on bank stability using a sample of 59 Islamic banks and 149 conventional banks from ten Muslim countries for the period of 2006 to 2016. Overall, in the case of Islamic banks, their results provide evidence in support of competition stability hypothesis. Recently, Risfandy et al. (2020) examined the competition-stability relationship for banks operating in dual banking system from 29 countries for the period of 2010 to 2018 . They found that competition impedes the stability of conventional banks.

\section{VARIABLE CONSTRUCTION AND METHODOLOGY}

\subsection{Bank Competition}

An important step is the measurement of competition. Cetorelli and Strahan (2006) use concentration to measure bank competition by following the earlier tradition of industrial organization. However, it is a widely held belief that concentration measures may reveal important industry structural characteristics, but it is not a good indicator of competition (Beck et al., 2006; Claessens \& Laeven, 2004). In contrast, the use of Lerner indices (Lerner, 1934) or price-cost based margin as a measure of competition has been advocated by recent literature.

Calculation of Lerner index requires knowing the marginal cost. Since marginal cost data is often not available, the first significant step in constructing a competition index is to use econometric methods to estimate marginal costs. The measurement of competition has used in industrial organizations for a number of years, dating back to Lerner (1934). Lerner is defined as a "monopoly power index or degree of monopoly as pi minus mci divided by pi, where pi represents firm's price and mci represents firm's marginal cost respectively' (Lerner, 1934). This index ranged a value between 0 and 1 . Zero reflects perfect competition and increasing values indicates higher market power. Specifically, the Lerner index is constructed as the price (P) and marginal cost (MC) of a firm. The higher the number index scored implies greater market power. The range varies from 1 (being high) to 0 (being low). Many research studies of banking have frequently employed Lerner index as it is constructed on markups in banking. This measure compares the output prices (revenues) and marginal costs (costs) differences. The total revenue over total assets is a formula used to obtain output prices, and trans-log cost function is estimated with respect to output to obtain the marginal costs. The higher values, inclining to 1 , show lower bank competition and lower values, inclining to 0 , show high bank competition. Hence, values are closer to 0 in cases of perfect competition and 1 for pure monopoly. The detail computation of the Lerner index can be found in appendix A.1.

\subsection{Bank Stability and Control Variable}

This study used the Z-score ratio as measure of bank stability, as taken in prior studies (see, e.g., Abedifar et al., 2013; Ibrahim and Rizvi, 2017; Mollah et al., 2017, among others). Using accounting information on asset returns, its volatility and leverage, the Z-score is calculated as follows: 


$$
Z_{-} \text {score }=\frac{R O A+(E T A)}{\sigma(R O A)}
$$

Where, ROA is the return on assets, ETA is the equity divided by total assets and $\sigma(\mathrm{ROA})$ is the standard deviation of return on assets. This can be interpreted as the number of standard deviations by which returns would have to fall to wipe out all equity of the bank (Roy, 1952), therefore, Zscore can be viewed as the inverse of the probability of bank insolvency. A higher value denotes a higher level of the soundness of the bank, or alternatively speaking, a lower value denotes the bank's higher exposure to insolvency risks.

Based on existing studies, this study included following variables from banking and finance literature. Particularly, this study control for bank size, because the business model and clients of larger banks are different from smaller banks (De la Torre et al., 2008). The prior literature also shows the relationship between Non-interest income and bank soundness and risk taking. For example, Köhler (2014) find that non-interest income is positively correlated with systemic risk and impact bank soundness. Similarly, Bostandzic and Weiss (2018) find that European banks contribute more to systemic risk than U.S. banks do, and this increase in systemic risk is higher when banks have more non-interest income.

In addition, this study uses four board level variables, Board Size, Auditing Committee Independence, Risk Management Committee and Female Board Representation in order to control for board characteristics. This study control for Board Size, because previous studies (Faleye \& Krishnan, 2017; Fernandes \& Fich, 2016) find that Board Size is significantly related to bank performance and bank soundness. The extant literature also shows that bank boards with an independent auditing committee and a separate risk management committee are more effective in monitoring managers and their bank stability (see, Carter et al., 2010; Green \& Homroy, 2018, among others). Therefore, two dummy variables-Auditing Committee Independence and Risk Management Committee- are included in our model. They take the value one if the Auditing Committee is independent and there is a separate Risk Management Committee in the organization structure of the board, respectively. Finally, Female Board Representation is used for control variable because there is an ongoing debate in academia regarding female board representation and bank risk-taking and stability, and empirical findings are inconclusive. Some studies find a positive (Campbell \& Minguez-Vera, 2008; Liu et al., 2014; Post \& Byron, 2015; Terjesen et al., 2016), whereas others report a negative (Adams \& Ferreira, 2009; Ahern \& Dittmar, 2012) or even nonexistent (Carter et al., 2010; Chapple \& Humphrey, 2014) relationship between female board representation and bank soundness. Female Ratio represents the share of female directors in the board (see Levi et al., 2014; Sila et al., 2016).

\subsection{Econometric Specifications}

The objective of this study is to examine whether the relationship between competition and bank stability is significantly different for Islamic banks vis-a-vis conventional banks. Existing studies, for example Mollah and Zaman (2015) and Bitar and Tarazi (2019) provide comparative analyses of financial stability, risk management, and performance between these two types of banks by introducing dummy variable approach. These studies have used Generalized Least Squares (GLS) regressions and the coefficients are estimated by using random-effects estimator. We use the 
Hausman test ${ }^{2}$ for the choice of our model and result shows that random-effects estimator is preferable to the fixed-effects estimator. The use of GLS technique is more appropriate for two reasons. First, regression models such as OLS ignore the panel structure of our data. Second, the fixed-effects estimator could lead to imprecise estimates when the key regressors do not vary much over time (Semykina \& Wooldridge, 2010, pp 326), which corresponds to the Islamic bank dummy variable in our case. We employ the following regression model:

$$
\begin{gathered}
Z-\text { Score }_{i t}=\varphi_{0}+\varphi_{1} I \text { IB_Dummy }_{i t}+\varphi_{2} \text { LER }_{i t}+\varphi_{3} I B_{-} \text {Dummy }_{i t} * \text { LER }_{i t}+ \\
\theta_{1} \text { Bank_Size }_{i t}+\theta_{2} \text { Ownership_Structure }_{i t}+\theta_{3} \text { Board_Size }_{i t}+\theta_{4} \text { Audit Committe }_{i t}+ \\
\theta_{5} \text { Risk_Management }_{i t}+\theta_{6} \text { Female_Ratio }_{i t}+\mu_{i t}
\end{gathered}
$$

In equation 2, the dependent variable is a bank's Z-Score estimated as capital asset ratio plus return on assets divided by sigma of return on assets. LER is the Lerner index score estimated from trans$\log$ cost function using quantity of output, input prices and time trend.

IB_Dummy $\mathrm{i}_{\mathrm{i}, \mathrm{t}}$ is a dummy variable that takes the value one if bank type is Islamic bank and zero otherwise. It controls for the difference in the stability between Islamic and conventional banks. $\mathrm{LER}_{\mathrm{i}, \mathrm{t}} \times \mathrm{IB}_{-}$Dummy $i, t$ is the interaction term and our variable of interest. The coefficient $\varphi_{3}$ shows whether the relationship between the competition and stability is significantly different for Islamic banks compared to their conventional counterparts.

\subsection{Sample and Data Source}

The population of the study is financial sector. The sample consists of Islamic and conventional banks working in Pakistan. This study has taken the data from BankScope database from 1996 to 2013. Appendix A.2 shows the list of Islamic and conventional banks which are incorporated in the sample. Moreover, all bank level variables are winsorized at a $1 \%$ tail to mitigate the problem of outliers.

\section{RESULTS}

\subsection{Competition and bank stability: Baseline results}

Table 1 presents the baseline results regarding competition and bank stability relationship. The relationship between competition and stability is estimated using random effects model. The stability is proxied by the Z-score while competition is measured by Lerner index. For the computation of results in table 1, Z-score is regressed on our IB_Dummy (Islamic bank dummy variable), Lerner index and control variables.

\footnotetext{
${ }^{2}$ Our selection of model is based on Hausman Test (Fixed versus Random Effects). Following are the null and alternate hypotheses are tested for the choice of model; H0, random effect is more appropriate, H1: fixed effect is more appropriate. Our results show that null hypothesis is not rejected; hence random effects model is used.
} 
Table 1: Baseline results for competition and bank stability

\begin{tabular}{|c|c|c|c|}
\hline Variable & Coefficient & t-Statistic & Prob. \\
\hline $\begin{array}{l}\text { LER } \\
\end{array}$ & $\begin{array}{c}6.456 * * * \\
-2.117\end{array}$ & 3.05 & 0.000 \\
\hline IB_Dummy & $\begin{array}{c}3.665 * * * \\
-1.271\end{array}$ & 2.884 & 0.002 \\
\hline GFC & $\begin{array}{c}-1.177 * * \\
-0.589\end{array}$ & -1.998 & 0.050 \\
\hline Bank Size & $\begin{array}{c}3.223 * * * \\
-1.158\end{array}$ & 2.783 & 0.004 \\
\hline Non-interest income & $\begin{array}{c}0.426 * * * \\
-0.139\end{array}$ & 3.065 & 0.000 \\
\hline Board Size & $\begin{array}{c}0.345 * * * \\
-0.044\end{array}$ & 7.841 & 0.000 \\
\hline Female Ratio & $\begin{array}{c}0.143 * * * \\
-0.048\end{array}$ & 2.979 & 0.001 \\
\hline Auditing Committee & $\begin{array}{c}0.273 * * * \\
-0.114\end{array}$ & 2.395 & 0.019 \\
\hline Risk Management & $\begin{array}{c}2.92 * * * \\
-1.042\end{array}$ & 2.802 & 0.004 \\
\hline Const. & $\begin{array}{c}1.679 \\
-1.765\end{array}$ & 0.951 & 0.250 \\
\hline $\begin{array}{l}\text { Number of Bank } \\
\text { p-value (F-statistic) } \\
\text { Adjusted R-squared }\end{array}$ & $\begin{array}{c}38 \\
0.000 \\
0.556 \\
\end{array}$ & & \\
\hline
\end{tabular}

This table shows the results of Generalized Least Squares (GLS) regressions and the coefficients are estimated by using random-effects estimator. A panel of 38 cross-sections is estimated in e-views over the fifteen years period from 1996 to 2013. In the estimated equation, the dependent variable is a bank's Z-Score measured as capital asset ratio plus return on assets divided by sigma of return on assets. LER is the Lerner index score estimated from trans-log cost function using quantity of output, input prices and time trend. IB_Dummy is a dummy variable that takes the value one if bank type is Islamic bank and zero otherwise. Moreover, GFC represents the global financial crisis. Robust standard-errors are reported in parentheses***, **, and *indicate significance at $1 \%, 5 \%$, and $10 \%$, respectively

The slope parameter $\varphi_{1}$ assumes that Islamic and conventional banks are different in terms of stability. The result shows that the coefficient of IB_Dummy $\left(\varphi_{1}\right)$ is significant means that stability of Islamic banks is significantly different from than their conventional counterparts.

The slope parameter $\varphi_{2}$ captures the relationship between the competition and stability for conventional banks. The coefficient of Lerner index $\left(\varphi_{2}\right)$ is significant and positively associated with Z_Score implying that overall rise in competition results in the stability of conventional banks. This finding supports the competition stability view and consistent with existing literature (Clark et al., 2018; Goetz, 2018; Islam et al., 2020; Saif-Alyousfi et al., 2020, among others).

Moreover, the negative and significant coefficient of global financial crisis and bank stability suggest that banking crisis adversely impacted the conventional banks in Pakistan. Further, the control variables have expected signs. For instance, banks size is significant and positive suggest that larger bank are more stable that is in-line with the economies of scales effect for big banks. Likewise, the coefficients of female ratio and risk management committee are significant and positive implies that presence of female on the board and having a risk management committee improves bank stability. These results are consistent with previous studies, which argue that banks 
having female board representation and strong risk management committee face lower risk taking (Faccio et al., 2016; Green \& Homroy, 2018; Khan et al., 2020; Perryman et al., 2016).

\subsection{Competition and bank stability: Islamic vs conventional banks}

So far, our results indicate that the competition is significanlty associated with stablity of both Islamic and conventional banks. In this sub-section, our objective is to explore whether the relationship between competition and stability is different for Islamic banks compared to conventional banks. To achieve this objective, an interaction term of Islamic banks dummy with Lerner index is introduced into the model. The slope parameter $\varphi_{3}$ captures whether the relationship between the competition and bank stability is significantly different for Islamic banks compared to their conventional counterparts.

Table 2 presents the results for the difference in the relationship between competition and stability of Islamic and conventional banks. The coefficient of the interaction term of Islamic banks dummy with Lerner index is positive and significant showing that in competitive environment Islamic bank are found to be more stable than their conventional counterparts in Pakistan. Alternatively speaking, conventional banks are found to be less stable than Islamic banks in competitive environment.

Our results are consistent with findings of existing studies on the association between competition and stability in dual banking system. For instance, Alam et al. (2019) investigated the competitionstability relationship in dual banking system. Their results support the competition-stability view for Islamic banks. In this research stream, Risfandy et al. (2020) examined the competition-stability relationship for banks operating in dual banking system and reported that competition impedes the stability of conventional banks as compared to their Islamic counterparts. Overall, our results support the competition stability view for Islamic banks operating in Pakistan. Moreover, the interaction term for GFC (global financial crisis) also significant and positive implies that Islamic banks were more stable in crisis period than their conventional counterparts.

Table 2: Competition and bank stability in Islamic and conventional banking system

\begin{tabular}{llll}
\hline \hline Variable & Coefficient & t-Statistic & Prob. \\
\hline LER & $6.452 * * *$ & 4.551 & 0.000 \\
IB_Dummy & -1.418 & & \\
& $2.821 * * *$ & 6.469 & 0.000 \\
GFC & -0.436 & & \\
& $-1.265 * * *$ & -3.626 & 0.001 \\
IB_Dummy*LER & -0.349 & & \\
& $1.727 * * *$ & 3.003 & 0.004 \\
IB_Dummy*GFC & -0.575 & & \\
& $0.091 * *$ & 2.521 & 0.017 \\
Bank Size & -0.036 & & \\
& $2.947 * * *$ & 7.454 & 0.000 \\
Non-interest income & -0.395 & $3.682 * * *$ & 0.000 \\
Board Size & -0.12 & & \\
& $0.263 * * *$ & 7.735 & 0.000
\end{tabular}




\begin{tabular}{|c|c|c|c|}
\hline \multirow{3}{*}{ Female Ratio } & -0.034 & & \\
\hline & $0.142 * * *$ & 4.585 & 0.000 \\
\hline & -0.031 & & \\
\hline \multirow[t]{2}{*}{ Auditing Committee } & 0.123 & 0.177 & 0.393 \\
\hline & -0.697 & & \\
\hline \multirow[t]{2}{*}{ Risk Management } & $2.786 * * *$ & 9.585 & 0.000 \\
\hline & -0.291 & & \\
\hline \multirow[t]{2}{*}{ Const. } & 5.453 & 1.495 & 0.131 \\
\hline & -3.648 & & \\
\hline Observation & 684 & & \\
\hline Number of Bank & 38 & & \\
\hline p-value (F-statistic) & 0.000 & & \\
\hline Adjusted R-squared & 0.763 & & \\
\hline \multicolumn{4}{|c|}{$\begin{array}{l}\text { This table shows the results of Generalized Least Squares (GLS) regressions and the coefficients are estimated by using } \\
\text { random-effects estimator. A panel of } 38 \text { cross-sections is estimated in e-views over the fifteen years period from } 1996 \text { to } \\
\text { 2013. In the estimated equation, the dependent variable is a bank's Z-Score measured as capital asset ratio plus return on } \\
\text { assets divided by sigma of return on assets. LER is the Lerner index score estimated from trans-log cost function using } \\
\text { quantity of output, input prices and time trend. IB_Dummy is a dummy variable that takes the value one if bank type is } \\
\text { Islamic bank and zero otherwise. Moreover, GFC represents the global financial crisis. IB_Dummy*LER and } \\
\text { IB_Dummy*GFC are the interaction terms of Islamic dummy with Lerner index and global financial crisis. Interaction } \\
\text { terms capture the deferential effect of competition and financial crisis on bank stability for Islamic and conventional banks. } \\
\text { Robust standard-errors are reported in parentheses***, **, and *indicate significance at } 1 \%, 5 \% \text {, and } 10 \% \text {, respectively. }\end{array}$} \\
\hline
\end{tabular}

\subsection{Further investigation}

In this section, mean comparison analysis is used in order to compare the mean stability score and degree of competiveness for the group of Islamic and conventional banks. Results are presented in Table 3 . These results are confirmed by mean comparison analysis, which shows the mean stability score and degree of competitiveness is lower in conventional banks and Islamic banks groups respectively as compared to another group.

Table 3: Bank competition in Islamic and conventional banks and financial stability

\begin{tabular}{|c|c|c|c|c|c|}
\hline \multicolumn{6}{|c|}{ Panel A: Bank Stability } \\
\hline \#Obs. & Mean IB & & Std. Dev. & SE Mean & $\begin{array}{l}\text { Test Value Z-score } \\
\text { CB }\end{array}$ \\
\hline 9 & 26.23 & & 14.41 & 4.80 & 10.59 \\
\hline Test stat & df & Sig. (2-tailed) & Mean Diff & LLCI@95\% & ULCI@95\% \\
\hline 3.257 & 8 & 0.012 & 15.64 & 4.567 & 26.719 \\
\hline \multicolumn{6}{|c|}{ Panel B Competition } \\
\hline \#Obs. & Mean IB & & Std. Dev. & SE Mean & $\begin{array}{l}\text { Test Value Lerner } \\
\text { Index CB }\end{array}$ \\
\hline 9 & 0.528 & & 0.0277 & 0.0092 & 0.443 \\
\hline Test stat & df & Sig. (2-tailed) & Mean Diff & LLCI@95\% & ULCI@95\% \\
\hline-9.196 & 8 & 0 & -0.085 & -0.1063 & -0.0637 \\
\hline
\end{tabular}

Panel A shows the result of one sample test for Z-Score, where the test value Z-score is the average value of Z-score for conventional banks (CB). Panel B shows the result of one sample test for Lerner index, where the Lerner index test value is the average value of Lerner index for CB. IB indicates Islamic banks. 
Moreover, the average score of bank stability and competition is calculated for sample banks and reported in table 4. For this purpose, the sum of Lerner index and Z-score of all years for each bank is individually divided by the number of years.

Table 4: Competition and stability: Average score of Islamic and conventional banks

\begin{tabular}{|c|c|c|c|c|}
\hline Category & Name of Bank & Years & Lerner Index & Z-Score \\
\hline Conventional & Allied Bank Limited & 17 & 0.355 & 4.7 \\
\hline Conventional & American Express Bank Limited & 4 & 0.361 & 14.2 \\
\hline Conventional & Askari Bank Limited & 16 & 0.384 & 5.9 \\
\hline Conventional & Atlas Bank Limited & 6 & 0.816 & 17.9 \\
\hline Conventional & Bank Al Habib & 17 & 0.68 & 5.6 \\
\hline Conventional & Bank Alfalah Limited & 16 & 0.43 & 5.2 \\
\hline Conventional & Bank of Khyber & 16 & 0.59 & 11.2 \\
\hline Conventional & Bank of Puniab & 18 & 0.55 & 7.8 \\
\hline Conventional & Favsal Bank Ltd & 17 & 0.493 & 9.9 \\
\hline Conventional & First Dawood Investment Bank Limited & 9 & 0.25 & 15.2 \\
\hline Conventional & First Women Bank Limited & 15 & 0.3 & 7.3 \\
\hline Conventional & Habib Bank Limited & 19 & 0.215 & 6.2 \\
\hline Conventional & Habib Metropolitan Bank Limited & 17 & 0.505 & 7.5 \\
\hline Conventional & Indus Bank Limited & 8 & 0.368 & 18 \\
\hline Conventional & JS Bank Limited & 8 & 0.366 & 17.9 \\
\hline Conventional & KASB Bank Limited & 17 & 0.464 & 9.5 \\
\hline Conventional & MCB Bank Limited & 17 & 0.256 & 8.7 \\
\hline Conventional & Mybank Ltd & 16 & 0.525 & 11.7 \\
\hline Conventional & National Bank of Pakistan & 17 & 0.458 & 9.1 \\
\hline Conventional & NIB Bank Ltd & 11 & 0.533 & 12.9 \\
\hline Conventional & PICIC Commerical Bank Limited & 13 & 0.151 & 9.1 \\
\hline Conventional & Royal Bank of Scotland Ltd (The) & 16 & 0.608 & 8.4 \\
\hline Conventional & Samba Bank Limited & 11 & 0.612 & 25.8 \\
\hline Conventional & Silkbank Limited & 17 & 0.497 & 5.3 \\
\hline Conventional & Soneri Bank Limited & 16 & 0.45 & 7.5 \\
\hline Conventional & Standard Chartered Bank Limited (Paksitan) & 8 & 0.383 & 15.5 \\
\hline Conventional & Summit Bank Limited & 8 & 0.475 & 1702 \\
\hline Conventional & Union Bank Limited & 14 & 0.363 & 6.4 \\
\hline Conventional & United Bank Limited & 17 & 0.412 & 5.8 \\
\hline Islamic & Albaraka Bank (Pakistan) Limited & 7 & 0.363 & 17 \\
\hline Islamic & Albaraka Islamic Bank BSC (EC) & 7 & 0.754 & 12.4 \\
\hline Islamic & Bank Islam Pakistan Limited & 10 & 0.452 & 25.1 \\
\hline Islamic & Buri Bank Limited & 8 & 0.571 & 37.6 \\
\hline Islamic & Dubai Islamic Bank Pakistan Limited & 9 & 0.458 & 26.7 \\
\hline Islamic & First Habib Modaraba & 11 & 0.805 & 58.8 \\
\hline Islamic & First National Bank Modaraba & 9 & 0.402 & 15.6 \\
\hline Islamic & Meezan Bank Limited & 14 & 0.647 & 1703 \\
\hline Islamic & Standard Chartered Modaraba & 9 & 0.301 & 25.6 \\
\hline
\end{tabular}

Source: Authors' Calculations 


\section{CONCLUDING REMARKS}

Existing literature, in general, has focused on the competition stability nexus for conventional and Islamic banking. However, no research has been done in the context of Pakistani banks. Moreover, comparative evidence on this relationship across dual banking systems is a demanded topic. This paper addresses these issues and analyses and compares the bank competition and financial stability of Islamic and conventional banks in Pakistan. Panel data for 29 Islamic and conventional banks of Pakistan for the period starting from 1996 to 2013 is used and analyzed. Diagnostic tests namely redundant fixed effect and Hausman test suggest the existence of random effect model in panel estimation. The results of this panel generalized least square show that both Islamic banks and conventional banks are different in terms of financial stability. Further, an interaction term of Islamic banks dummy with Lerner index is used to explore whether the relationship between competition and stability is different for Islamic banks compared to conventional banks. Overall, Islamic banks are found to be more stable than conventional banks in competitive environment. These results are confirmed by mean comparison analysis, which shows the mean stability score and degree of competitiveness is lower in conventional banks and Islamic banks groups respectively as compared to another group.

This paper provides an important contribution in the context of Pakistan using direct measure of bank competition. The results provide useful insight for regulators decisions about devising the appropriate competition policy. Besides, the objective of developing Sharia compliant banking, this study encourages motive from the perspective of stability of banking system and economy of the country as well. Conventional bank may start their Islamic windows (which has been established in some banks) to improve its stability.

\section{REFERENCES}

Abedifar, P., Giudici, P., \& Hashem, S. Q. (2017). Heterogeneous market structure and systemic risk: Evidence from dual banking systems. Journal of Financial Stability, 33, 96-119.

Abedifar, P., Hasan, I., \& Tarazi, A. (2016). Finance-growth nexus and dual-banking systems: Relative importance of Islamic banks. Journal of Economic Behavior \& Organization, 132, 198-215.

Abedifar, P., Molyneux, P., \& Tarazi, A. (2013). Risk in Islamic banking. Review of Finance, 17(6), 2035-2096.

Adams, R. B., \& Ferreira, D. (2009). Women in the boardroom and their impact on governance and performance. Journal of financial economics, 94(2), 291-309.

Ahern, K. R., \& Dittmar, A. K. (2012). The changing of the boards: The impact on firm valuation of mandated female board representation. The quarterly journal of economics, 127(1), 137-197.

Alam, N., Hamid, B. A., \& Tan, D. T. (2019). Does competition make banks riskier in dual banking system?. Borsa Istanbul Review, 19, S34-S43.

Albaity, M., Mallek, R. S., \& Noman, A. H. M. (2019). Competition and bank stability in the MENA region: The moderating effect of Islamic versus conventional banks. Emerging Markets Review, 38, 310-325.

Allen, F., \& Gale, D. (2004). Competition and Financial Stability. Journal of Money, Credit, and Banking, 36(3), 453-480. 
Azmi, W., Ali, M., Arshad, S., \& Rizvi, S. A. R. (2019). Intricacies of competition, stability, and diversification: Evidence from dual banking economies. Economic Modelling, 83, 111126.

Beck, T., De Jonghe, O., \& Schepens, G. (2013). Bank competition and stability: Cross-country heterogeneity. Journal of Financial Intermediation, 22(2), 218-244.

Beck, T., Demirgüç-Kunt, A., \& Levine, R. (2006). Bank concentration, competition, and crises: First results. Journal of Banking and Finance, 30(5), 1581-1603.

Bitar, M., \& Tarazi, A. (2019). Creditor rights and bank capital decisions: Conventional vs. Islamic banking. Journal of Corporate Finance, 55, 69-104.

Boot, A. W., \& Thakor, A. V. (1993). Self-interested bank regulation. The American Economic Review, 83(2), 206-212.

Bostandzic, D., \& Weiss, G. N. (2018). Why do some banks contribute more to global systemic risk?. Journal of Financial Intermediation, 35, 17-40.

Boyd, J. H., \& De Nicoló, G. (2005). The theory of bank risk taking and competition revisited. Journal of Finance, 60(3), 1329-1343.

Campbell, K., \& Mínguez-Vera, A. (2008). Gender diversity in the boardroom and firm financial performance. Journal of business ethics, 83(3), 435-451.

Carter, D. A., D'Souza, F., Simkins, B. J., \& Simpson, W. G. (2010). The gender and ethnic diversity of US boards and board committees and firm financial performance. Corporate Governance: An International Review, 18(5), 396-414.

Cetorelli, N., \& Strahan, P. E. (2006). Finance as a barrier to entry: Bank competition and industry structure in local U.S. markets. Journal of Finance, 56, 437-461.

Chapple, L., \& Humphrey, J. E. (2014). Does board gender diversity have a financial impact? Evidence using stock portfolio performance. Journal of business ethics, 122(4), 709-723.

Claessens, S., \& Laeven, L. (2004). What Drives Bank Competition? Some International Evidence. Journal of Money, Credit, and Banking, 36(3), 563-583.

Clark, E., Radić, N., \& Sharipova, A. (2018). Bank competition and stability in the CIS markets. Journal of International Financial Markets, Institutions and Money, 54, 190203.

De la Torre, A., Soledad Martinez Peria, M., \& Schmukler, S. L. (2008). Bank involvement with SMEs: Beyond relationship lending. The World Bank.

Faccio, M., Marchica, M. T., \& Mura, R. (2016). CEO gender, corporate risk-taking, and the efficiency of capital allocation. Journal of corporate finance, 39, 193-209.

Faleye, O., \& Krishnan, K. (2017). Risky lending: does bank corporate governance matter?. Journal of Banking \& Finance, 83, 57-69.

Fernandes, N., \& Fich, E. M. (2016). Are Outside Directors with Greater Board Tenure Valuable? Evidence from the Last Credit Crisis. SSRN. https://doi.org/10.2139/ssrn.1409557

Goetz, M. R. (2018). Competition and bank stability. Journal of Financial Intermediation, 35, $57-$ 69.

Green, C. P., \& Homroy, S. (2018). Female directors, board committees and firm performance. European Economic Review, 102, 19-38.

Hanif, M. N. (2017). Measuring Competition in the Banking Sector of Pakistan: An Application of Boone Indicator. Journal of Independent Studies and Research-Management, Social Sciences and Economics, 15(2), 50-78.

Hasan, M., \& Dridi, J. (2011). The effects of the global crisis on Islamic and conventional banks: A comparative study. Journal of International Commerce, Economics and Policy, 2(2), 163-200. 
Ibrahim, M. H., \& Rizvi, S. A. R. (2017). Do we need bigger Islamic banks? An assessment of bank stability. Journal of Multinational Financial Management, 40, 77-91.

Ibrahim, M. H., Salim, K., Abojeib, M., \& Yeap, L. W. (2019). Structural changes, competition and bank stability in Malaysia's dual banking system. Economic Systems, 43(1), 111-129.

Ijaz, S., Hassan, A., Tarazi, A., \& Fraz, A. (2020). Linking bank competition, financial stability, and economic growth. Journal of Business Economics and Management, 21(1), 200-221.

Islam, M. A., Ebenezer, O. O., Sobhani, F. A., \& Shahriar, M. S. (2020). The effect of product market competition on stability and capital ratio of banks in Southeast Asian countries. Borsa Istanbul Review, 20(3), 292-300.

Kabir, M. N., \& Worthington, A. C. (2017). The 'competition-stability/fragility' nexus: A comparative analysis of Islamic and conventional banks. International Review of Financial Analysis, 50, 111-128.

Kasman, S., \& Kasman, A. (2015). Bank competition, concentration and financial stability in the Turkish banking industry. Economic Systems, 39(3), 502-517.

Keeley, M. C. (1990). Deposit insurance, risk, and market power in banking. American Economic Review, 80(5), 1183-1200.

Khan, M. H., Fraz, A., Hassan, A., \& Abedifar, P. (2020). Female board representation, risk-taking and performance: Evidence from dual banking systems. Finance Research Letters, 37, 101541.

Köhler, M. (2014). Does non-interest income make banks more risky? Retail-versus investmentoriented banks. Review of Financial Economics, 23(4), 182-193.

Lerner, A. P. (1934). Economic Theory and Socialist Economy. The Review of Economic Studies, 2(1), 51-61.

Levi, M., Li, K., \& Zhang, F. (2014). Director gender and mergers and acquisitions. Journal of Corporate Finance, 28, 185-200.

Liu, Y., Wei, Z., \& Xie, F. (2014). Do women directors improve firm performance in China?. Journal of corporate finance, 28, 169-184.

Mishkin, F. S. (1999). Global Financial Instability: Framework, Events, Issues. Journal of Economic Perspectives, 13(4), 3-20.

Mollah, S., \& Zaman, M. (2015). Shari'ah supervision, corporate governance and performance: Conventional vs. Islamic banks. Journal of Banking \& Finance, 58, 418-435.

Mollah, S., Hassan, M. K., Al Farooque, O., \& Mobarek, A. (2017). The governance, risk-taking, and performance of Islamic banks. Journal of Financial Services Research, 51(2), 195219.

Perryman, A. A., Fernando, G. D., \& Tripathy, A. (2016). Do gender differences persist? An examination of gender diversity on firm performance, risk, and executive compensation. Journal of Business Research, 69(2), 579-586.

Post, C., \& Byron, K. (2015). Women on boards and firm financial performance: A metaanalysis. Academy of management Journal, 58(5), 1546-1571.

Rashid, A., Yousaf, S., \& Khaleequzzaman, M. (2017). Does Islamic banking really strengthen financial stability? Empirical evidence from Pakistan. International Journal of Islamic and Middle Eastern Finance and Management, 29(2), 579-588.

Risfandy, T., Tarazi, A., \& Trinugroho, I. (2020). Competition in dual markets: Implications for banking system stability. Global Finance Journal, 100579.

Roy, A. D. (1952). Safety first and the holding of assets. Econometrica: Journal of the econometric society, 431-449. 
Saif-Alyousfi, A. Y., Saha, A., \& Md-Rus, R. (2020). The impact of bank competition and concentration on bank risk-taking behavior and stability: Evidence from GCC countries. The North American Journal of Economics and Finance, 51, 100867.

Semykina, A., \& Wooldridge, J. M. (2010). Estimating panel data models in the presence of endogeneity and selection. Journal of Econometrics, 157(2), 375-380.

Sila, V., Gonzalez, A., \& Hagendorff, J. (2016). Women on board: Does boardroom gender diversity affect firm risk?. Journal of Corporate Finance, 36, 26-53.

Terjesen, S., Couto, E. B., \& Francisco, P. M. (2016). Does the presence of independent and female directors impact firm performance? A multi-country study of board diversity. Journal of Management \& Governance, 20(3), 447-483. 